\title{
Means of Choice for Interactive Management of Dynamic Geometry Problems Based on Instrumented Behaviour
}

\author{
Philippe R. Richard ${ }^{1}$, Michel Gagnon ${ }^{2}$, Josep Maria Fortuny ${ }^{3}$, Nicolas Leduc ${ }^{2}$, Michèle Tes- \\ sier-Baillargeon ${ }^{1}$ \\ ${ }^{1}$ Département de didactique, Université de Montréal, Canada \\ ${ }^{2}$ Département de génie informatique et génie logiciel, École Polytechnique de Montréal, Canada \\ ${ }^{3}$ Departament de Didàctica de les Matemàtiques i de les Ciències Experimentals, Universitat Autònoma de Barcelona, Spain \\ Email: philippe.r.richard@umontreal.ca,michel.gagnon@polymtl.ca,josepmaria.fortuny@uab.es
}

Received 2013

\begin{abstract}
Our paper presents a project that involves two research questions: does the choice of a related problem by the tutorial system allow the problem solving process which is blocked for the student to be restarted? What information about learning do related problems returned by the system provide us? We answer the first question according to the didactic engineering, whose mode of validation is internal and based on the confrontation between an a priori analysis and an $a$ posteriori analysis that relies on data from experiments in schools. We consider the student as a subject whose adaptation processes are conditioned by the problem and the possible interactions with the computer environment, and also by his knowledge, usually implicit, of the institutional norms that condition his relationship with geometry. Choosing a set of good problems within the system is therefore an essential element of the learning model. Since the source of a problem depends on the student's actions with the computer tool, it is necessary to wait and see what are the related to problems that are returned to him before being able to identify patterns and assess the learning. With the simultaneity of collecting and analysing interactions in each class, we answer the second question according to a grounded theory analysis. By approaching the problems posed by the system and the designs in play at learning blockages, our analysis links the characteristics of problems to the design components in order to theorize on the decisional, epistemological, representational, didactic and instrumental aspects of the subject-milieu system in interaction.
\end{abstract}

Keywords: Didactics of Mathematics; Competencies; Geometric Thinking; Tutorial System; Related Problems; Dynamic Geometry; Instrumented Behavior; Cognitive Interactions; Conceptions; Mathematical Work Space; Means of Choice; Didactic Contract

\section{Foreword}

In the third year of secondary school, two students tried to solve a problem of proof at the interface of an interactive tutorial system. It was to compare the area of two triangles in a parallelogram and to proof the assumption made. After reading the statement and constructing or moving the elements of the figure in the dynamic geometry module (Figure 1), the students quickly agree on equal areas. They began to create a mathematical proof on the tutorial system interface and were therefore delighted to see that Prof. Turing, an artificial tutor agent, indicated with a smiley that their first intuition was well founded. Even though they were good students, they sometimes got stuck in their mathematical proof. Happily, with his messages, Prof. Turing was always successful in reviving the solution process. Without replacing the teacher, this tutor agent has 69,000 potential solutions "in mind" and was quickly able to target the solution envis- aged by the students, thereby providing personalized support. Prof. Turing also knows how to recognize a student's persistent difficulty and can suggest that he get help from his teacher. Furthermore, once he arrives, the teacher sees what has happened from the messages received but instead of insisting on their meaning in the context of the problem he rather asks that a new problem be solved. The students launched on paper without too much difficulty then one said to his companion: "look, I've got it... look, this is why it works!" And the solution to the original problem is relaunched. The use of a related problem therefore is a means of choice for this didactic system. Can they be made available to Prof. Turing?

\section{Introduction}

According to the theory of didactic situations, we know that the only way to "do" mathematics is to try and solve 
some specific problems and in this regard asking new questions. The teacher must therefore not communicate knowledge but pass on the right problem. If this transfer happens, the student plays the game and ends up winning, while learning takes place. But what if the student rejects or avoids the problem, or doesn't solve it? The teacher then has the social obligation to help him [7]. Set in didactics of mathematics, our research project is based on three key concepts: on the necessity of seeking and resolving specific problems for learning geometry in high school, on the assistance that makes up a transfer of the "right problems" in a context of instrumented learning, and on the voluntary but surprising action of the teacher who chooses to set a problem as a message to help a student whose solving of an initial problem remains blocked.

Instrumented learning is based on the use by the student of a tutorial system created by our research team for learning geometry. This system supports the student in solving problems of proof, issuing messages as needed (verbal or iconic expressions) appropriate to the actions of the student in the internal logic of problems. During a validation phase of previous research (see next section), the introduction of a support structure that incorporates a set of related problems appeared necessary to acquire the means of choice that the teacher discusses with his students. Unlike existing approaches, these problems do not divide the original problem into sub-strategies. With a completely new approach, the new problems arise from the characteristics of relationships between problems and learning blockages, engendering new decision means for the tutorial system.

\section{Research Program}

In this section, key words are in bold.

Based on the didactics of mathematics, our project is a continuation of the project a new approach to research on competential and instrumented learning of geometry in high school (CRSH 410-2009-0179) and it renews the foundations laid down in the article Didactic and theoretical-based perspectives in the experimental development of an intelligent tutorial system for the learning of geometry [41]. These works were common to the design of geogebraTUTOR, a tutorial system which is intended to support the development of students' mathematical competencies [29,46] and the construction

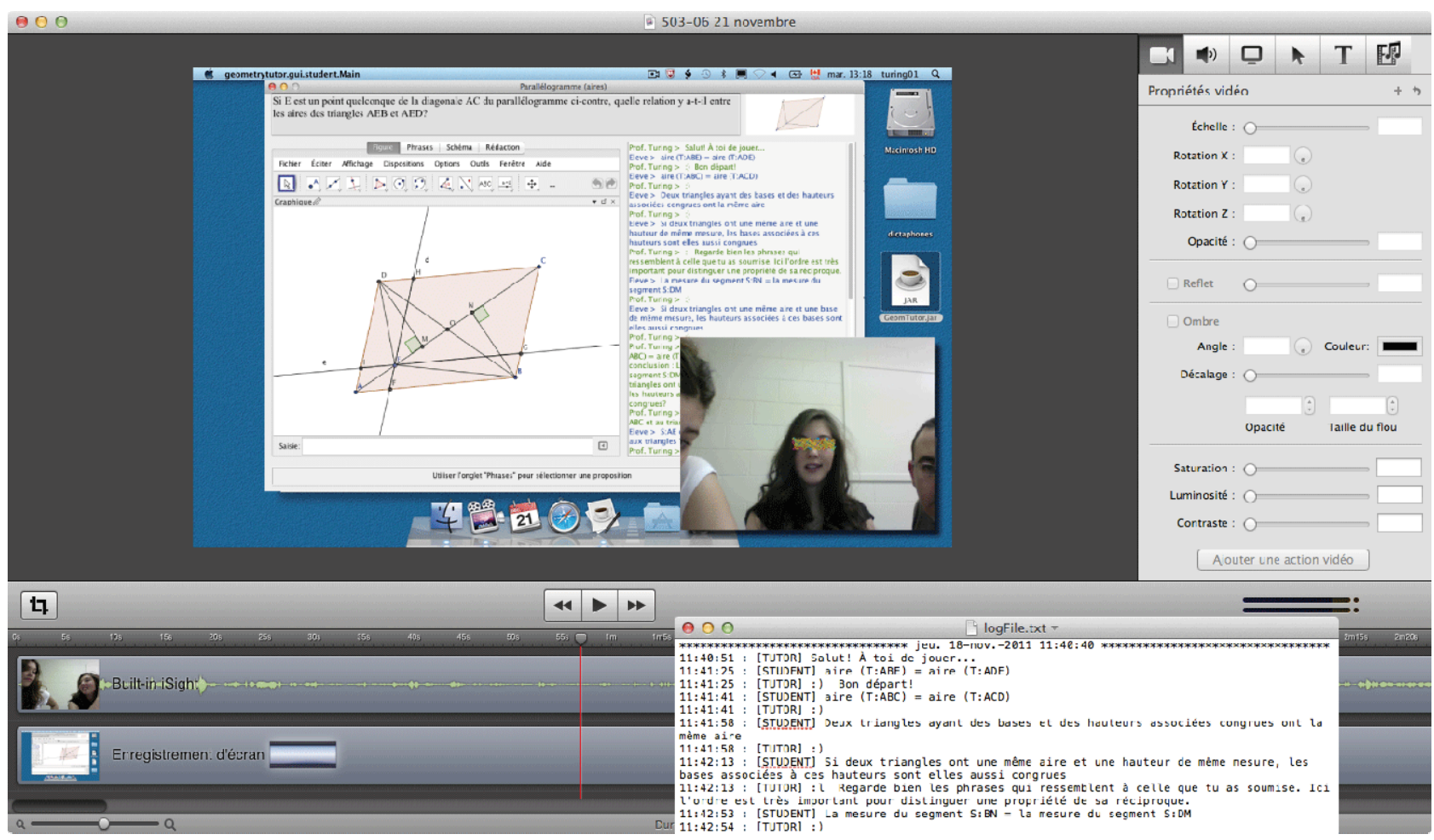

Figure 1. Analysis feature of interactions during solving of the parallelogram problem. In the background is the ScreenFlow software interface (recording sound, image and interaction on the screen) and in the foreground the log of the conversation between the student and the artificial tutor agent. On the student's screen, the "GeomTutor" Java applet launches the tutorial system and the "dictation" file saves the simultaneous recording of the teacher's intervention. The image used here shows the geometric (on the left) and discursive (on the right) modules but is hiding the modules for writing ("Statements" tab), structured arguments training ("Outline") and mathematical proof ("Writing"). For more information about the system's challenges, consult the video at http://www.matimtl.ca/evenements/evenement.jsp?id=106. 
of geometric thinking [19, 22, 47]. It consists of two subsystems, Turing ${ }^{1}$ (FQRSC 2005-AI-97435) and GeoGebra (http://www.geogebra.org/), a dynamic geometry software whose international influence is considerable in teaching mathematics and which includes a three dimensional geometry module in evolution [6]. By having to account for teacher intervention [49, 50], we have enriched our research program with assessment tools developed within Intergeo (http://i2geo.net), a consortium that manages a platform for sharing and assessment of the quality of resources to which our secondary mathematics teaching students have already contributed [51]. On the basis of these achievements, the current project still aims to improve learning but it now innovates by the original consideration of a structure of related problems which meets these student learning blockages, with a view to instrumented behaviour and whose reference geometry allows adaptation to actual class didactic contracts. Our reference to the decision-making theory of Schoenfeld [48] sheds light on both the resources, goals and orientations of the teacher intervention and the tutorial action, and the notions of conceptions [5] and mathematical work space [21] pose an epistemological, semiotic and instrumental view of cognitive interactions that emerge from the student cognitive interaction with the milieu. The notion of means of choice generalises the teacher's judgements and the decisions of the tutorial system when it returns a related problem following a learning blockage by the student, and that of a didactic contract designates the most frequently implicit expectations that there are for the student and the teacher respectively concerning mathematical knowledge.

\section{Objectives}

In seeking to better understand the means of choice for interactive management of dynamic geometry problems based on instrumented behaviour in high school, our research project has the objectives in the Table 1.

The idea of means of choice, as a voluntary action to consider one problem rather than another, transposes into decision making means within the tutorial system. We consider the instructional model (also known as instructional design) on two levels, that of didactics, the responsibility of active educational members and those in training, and that of the technology of computer programming and deployment, the responsibility of members with technological training (see the section Research team, latest results and student training). The achievement of our research objectives will have a direct affect on teacher training (Table 2).

\footnotetext{
${ }^{1}$ French acronym for TUtoRiel Intelligent en Géométrie and a nod to the engineer and mathematician Alan Mathison Turing.
}

\section{Background}

Well beyond the establishment of a simple online exerciser or a learning guide in a deterministic MOOC structure [16], our research project is based on a computerised environment for complex human learning which is in an international dynamic geometry movement where community development and sharing of reference activities are carried out among experts and teachers from different traditions. The idea of a tutorial system that supports students in problems of proofs is not new. Among first generation achievements, we can mention the Geometry Proofs Tutor [3], the Tigre-Mentoniezh project [32] and Géométrix (http://geometrix.free.fr/ by Jacques Gressier). All these systems are based on formal geometry models that, despite an evident advantage of computer programming, presuppose development in geometric thought

Table 1. The three general objectives.

\begin{tabular}{|c|c|}
\hline $\begin{array}{l}\text { Objective } 1 \\
\text { Instructional } \\
\text { model }\end{array}$ & $\begin{array}{l}\text { - Design, index, implement and test a structure } \\
\text { of related problems in a tutorial system } \\
\text { (geogebraTUTOR) which is based on the means } \\
\text { of usual choice for teacher intervention and the } \\
\text { instrumented behaviour of the student during } \\
\text { solving of fundamental problems involving proofs. }\end{array}$ \\
\hline $\begin{array}{l}\text { Objective } 2 \\
\text { Interpretation } \\
\text { and theorizing }\end{array}$ & $\begin{array}{l}\text { - Interpret and theorize on the decisional, } \\
\text { epistemological, representational, didactic and } \\
\text { instrumental aspects of the subject-milieu system } \\
\text { in interaction, with reference to the student's } \\
\text { conceptions and the mathematical workspace. }\end{array}$ \\
\hline $\begin{array}{l}\text { Objective } 3 \\
\text { Assessment } \\
\text { and control }\end{array}$ & $\begin{array}{l}\text { - Assess the consistency of the subject-milieu } \\
\text { system in interaction, with reference to the } \\
\text { development of mathematical competencies, } \\
\text { construction of geometric thought and the } \\
\text { student's learning in an instrumented perspective. }\end{array}$ \\
\hline
\end{tabular}

Table 2. The two training objectives.

- Support, by trainees (university students), of a part
of the cognitive, heuristic, semiotic and metamathe-
matical means made available to students during
simulated situations, to develop their ability to iden-
Initial training
tify with what the student knows and, reciprocally, to
test their teaching action.

Development of disciplinary competencies in geometry, as professional successor, critiques and interprets Continuing from its subjects or culture, in the exercise of his education functions.

- Richard, Cobo, Fortuny and Hohenwarter [40]

- Trgalová, Richard and Soury-Lavergne [52] 
by adherence to an axiomatic approach. Assisting student learning blockages is therefore formal. The same applies to second generation systems, although the interface, communication with the user and processing of significant actions are more developed. Among systems similar to geogebraTUTOR [42] should be mentioned the Advanced Geometry Tutor [28], the Baghera project [23], the Cabri-Euclide microworld [25] and the Geometry Explanation Tutor [1]. There is also the Andes Physics Tutor [54], for which some situations-problems are already premodeled in geometry.

Among the precursor achievements to our current system are AgentGeom [10] and Turing [39]. Unlike the systems which relate to formal axiomatic geometry, AgentGeom and Turing were developed on cognitive geometry models that lie between natural geometry and the axiomatic natural geometry of Kuzniak [20]. This allows full originality when considering situations-problems that bring together physical sciences to the process of discovery in mathematics [12], as Clairaut [9] appeared to desire in the Enlightenment by stating "this presumed induction carries its demonstration with it" (p. 64), following the representation on paper of a "dynamic" geometric figure [43]. In addition, although cognitive geometry is essential to considering reference geometry that is effectively practiced in the classroom, it allows for constitution of a structure of related problems that respond to informal learning blockages.

\section{References Axes of the Conceptual Framework}

\subsection{Epistemological Axis}

In the process of mathematical discovery, the epistemological dialectic of proofs and refutations of [24] considers the criticisms that arise with counter-examples in discussions between students and teacher. These criticisms are likely to require an adjustment of the conjecture, the proof or the counter-example itself, and also of knowledge and the problem. Although they can be seen as "breakpoints" [27] in solving a problem of proof, this is because like Lakatos we believe that the steps of proof are only summarised with formal or deductive approaches. In addition, we know that the supporting role of these criticisms can be incorporated into the steps of instrumented reasoning [18], while allowing the creation of a geometric workspace in continuity with the development of mathematical competencies inherited from elementary school [11]. Our desire to bring together the epistemology of mathematics into training programs, so the student can perform his work in geometry, is an attempt for subtle adaptation between an actual state of his mathematical competencies and the intrinsic requirement for performing geometry in class.

\subsection{Semiotic Axis}

When a study examines dynamic geometry and instrumented reasoning, questions on communications, processing of cognitive representations and objectivities of virtual representations are essential. The Duval's theory of language functions [13] sets out the conditions for learning based on the coordination of representation registers, of which the register of figures [14], and the functional-structural approach of Richard and Sierpinska [44] insists on the traditional semiotic means serving the quality of communications. When the student acts on a dynamic drawing, he is also acting on the system of representation, possibly for the communication of inductive reasoning [45]. This action can be the source of a learning blockage and, although the figural representations convey reasoning [36, 37] or simulate movement [2], they cannot generate it. In this context, a dynamic figure is also a kind of problem.

\subsection{Situational Axis}

In Brousseau's theory of didactical situations in mathematics [7], the main intervention of the teacher (arrow 1, Figure 2) occurs within a system which is itself in interaction, the student-milieu system (2), but with a didactic milieu which brings a tutor agent to him the role of arrows 1 and 2 is transposed with 6 and 7. According to [26], Brousseau will consider the subject-milieu interaction as the smallest unit of cognitive interactions. A state of equilibrium for this interaction defines a state of knowledge, the subject-milieu imbalance producing new knowledge (search for a new equilibrium)". However, the theory of didactic situations characterises each item of knowledge by situations that are specific to it, and the knowledge model of Balacheff and Margolinas [5] locates conceptions in the subject-milieu interaction, while first characterising a conception by the problems in which it is involved. If it results in a strong conceptual relationship between a moment of learning blockage and a related problem, it is also because a learning blockage is a breach of contract with what is expected in the context of the root problem and that the appearance of a new problem, in addition to relaunching the solving process, is not a sophisticated response suggestion which at its core considers the objective of the root problem.

\subsection{Instrumental Axis}

In Rabardel's theory of instrumentation [34], the instrument is the mode of action or thought constructed by the subject when he uses a tool; the manner in which the instrument is formed in the subject is the instrumental genesis. According to [21], instrumental genesis constitutes the geometric workspace and, when it is considered 
in the process of student-milieu interaction which creates its own space, instrumental genesis operates both during stages of discovery and validation [11]. Since the processes of instrumentation relate to the emergence and development of patterns of use and instrumented action, the progressive discovery of the tool's intrinsic properties by students, for whom the appearance of a related problem following a learning blockage is accompanied by the accommodation of their patterns and also changes in meaning of the instrument, results in association of the tool with new patterns [35]. The notions of conception and instrument occupy dual places in modelling of the subject-milieu [5].

\subsection{Decisional Axis}

The transposition of the teacher's intervention in the educational environment is necessarily accompanied by a transposition of means of the choice. Although these means can be interpreted in respect of a didactic contract, the implicitly shared significance that it supposes complicates understanding of the decisional process in all of the fundamental relationships. According to [7], the didactic contract is not really a true contract, since it is not explicit or voluntary and because neither the conditions for breach nor sanctions can be given in advance due to their didactic nature, which depends significantly on a knowledge of students that is as yet unknown. In Schoenfeld's decision making theory [48], if we know enough about what someone's resources, goals and orientations are, teacher or student, we can even come to understand, explain and model actions and decisions that seem unusual or abnormal. In the Introduction paragraph, the illustration of the sudden appearance of a new request for solving problem, while it was the first solving processed that was blocked, may surprise the observer but not the students, who are used to reacting to this type of requirement from their teacher.

\section{Methodology}

\subsection{General Direction}

As with our previous projects, we take advantage of a similar experimental effort to "verify a state or a change" and "develop accordingly". In fact, the illustration in the Foreword comes from an experiment (see the link below Figure 1 and [50] which allowed, firstly, verification of the validity of a structure of messages from the tutor agent when two classes of high school students resolved problems of proof and, secondly, identification of the means of choice of their teachers with the use of related problems after indexation of conceptual, heuristic, semiotic and met mathematical criteria [42]. This requirement invites us to consider together two paradigms on the epistemological didactic level. On the conceptual side, the learning models that we claim identify with the use of our tutorial system based on the preceding axes. On the methodological side, the approach implemented combines the didactic engineering of Artigue [4] and the grounded theory analysis of Glaser and Strauss [17]. Since the functional integration of a structure of related problems in the instructional model is in line with our project (see Acknowledgements), we can achieve objectives 1 and 3 with a confirmatory model [53] of the hypothesis-deduction type [4]. But the intervention of these problems depends on the instrumented behaviour, and since they generate a non-deterministic learning itinerary (following related problems), the emergence of learning models adapted to the use of an advanced tutorial system commits us to achieving objective 2 using a comparative-inductive type model [17].
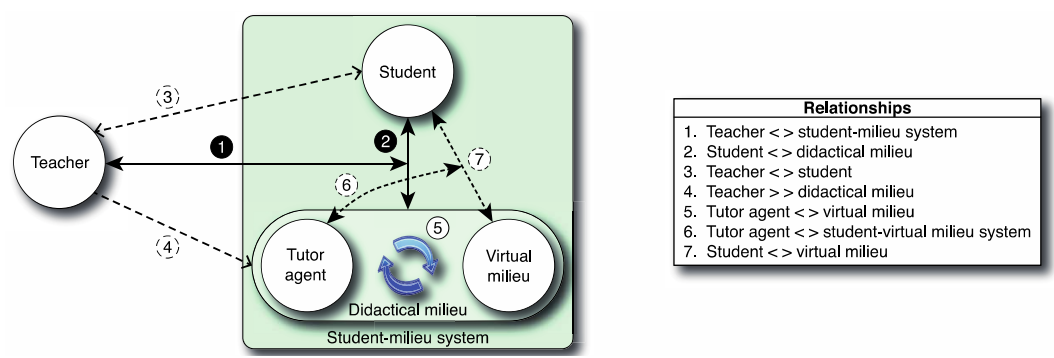

Figure 2. Fundamental relationships in the research system. It is an adaptation of [7] on the relationship of 1 to 4 between the teacher, the student and the milieu [41].

\subsection{Description of Key Activities and Specific Procedures}

Here is a brief description of phases of the research in relation to the objectives, for trimester $\mathrm{Q}$.

Phase $1\left(\mathrm{Q}_{1-2}\right) \downarrow$ Conception of the instructional model- preparation of objective 1 ( $1^{\text {st }}$ part $)$

-From the 34 problems based on [33] and adaptation 
of these to the curriculum in effect in the regions of the participating researchers, characterisation of problems according to the identity of problems [38] and indexation of them according to the above criteria.

- Implementation in geogebraTUTOR of a structure of related problems and testing experts on the functioning of the didactic milieu according to the learning model of [41].

Phase $2\left(\mathrm{Q}_{3-4}\right) \downarrow 1^{\text {st }}$ experiment in the schools achievement of objective 1 ( $1^{\text {st }}$ part)

To validate by cross-referencing primitive sources - or "triangulation" [15]:

-Collection of student-milieu interactions and teacher interventions in 3 classes of second cycle of high school in three different regions when, in their normal courses, students solve five problems of proof using the system interface (qualitative data, [30]).

- Request to teachers to reconstruct their interventions and compare the means of choice of the tutorial system with the didactic contract of the course $[31,8]$ during 50 minute explanatory discussions [55].

In addition to the log files, there will be "ScreenFlow" records (see Figure 1) for a sample of 24 volunteer students (4 teams of 2 per class), as well as audio recordings for the teachers of each class (intervention in class and explanatory discussions), in accordance with the ethical rules in force - ditto for entering and processing data in all phases.

Phase $3\left(\mathrm{Q}_{5-6}\right) \downarrow$ Analysis and interpretation - preparation of objectives 2 and 3 ( $1^{\text {st }}$ part)

-Analysis of times of learning blockage - or breakpoints - according to the knowledge model of Balacheff and Margolinas [5] by characterising conceptions $\mathbf{C}$ by a defining set of problems (P) for which solving tools (R) are provided based on representation systems (L) and a control structure $(\Sigma)$ which permits judgements and decisions.

-Interpretation of times of learning blockage by joining the student's conceptions $\mathbf{C}=(\mathrm{P}, \mathrm{R}, \mathrm{L}, \Sigma)$ with the characteristics of the related problems in play (of the system, phase 1; of teachers, phase 2).

Phase $4\left(\mathrm{Q}_{7-8}\right) \downarrow$ Cross-referencing, validation and fine-tuning - preparation for objective $1\left(2^{\text {nd }}\right.$ part $)$ and achievement of objective $2\left(1^{\text {st }}\right.$ part)

-Pooling of the results of phase 3 between researchers and identification of patterns.

- To improve the instructional model and better understand the common or invariant characteristics of the subject-milieu system in interaction, expert validation of the combination of phase 3 .

- Optimisation of the articulation and continuity between the conception of the tutorial system and pursuit of the conception during solving by the students (or "con- ception in use", [34]).

Phase $5\left(\mathrm{Q}_{9-10}\right) \downarrow 2^{\text {nd }}$ experiment in the schools preparation of objective 3 ( $2^{\text {nd }}$ part) and achievement of objective 1 ( $2^{\text {nd }}$ part)

-Resumption of the procedures for phase 2 , by this time asking teachers to assess the solutions (without noting them) with a view to assessing competencies [38].

Phase $6\left(\mathrm{Q}_{11-12}\right) \downarrow$ Modelling, synthesis, theorisation achievement of objectives 2 ( $2^{\text {nd }}$ part $)$ and 3

-Modelling of an ontology on the basis of didactic contracts and instrumented behaviour.

-Summary of the non-deterministic learning itineraries and underlying means of choice.

-Theorisation on the fundamental relationships of the instrumented didactic situation (Figure 2).

\section{Knowledge Mobilisation Plan}

As a human sciences discipline, the teaching of mathematics has a scientific side and a professional side, including the initial and continuing training of teachers in the field. When a project involves not only teaching theories but also construction of computer environments for human learning, questions arise in a very practical way, which leads to seeking a functional modelling of knowledge by making distinctions that are useful feedback for the teaching of mathematics as a whole. Our plan for knowledge mobilisation, similar to that which is grounded in our research program, aims to continue the multidirectional exchange of knowledge between researchers, teachers and other persons involved in the world of teaching mathematics, in a collaborative spirit of sharing which includes quality, integration and popularisation. We can summarise the overall mobilisation plan in terms of places $^{2}$ :

-Publication in journals for the quality of the research (ESM, IJCML, ZDM, etc.), its integration (ADSC, REC, $\mathrm{PME}$, etc.) and its popularisation (AMQ, PME, UNO, etc.);

- Organisation and participation in international symposia on teaching mathematics (EMF, ETM, CERME, etc.) as well as mathematics classroom technologies (INTERGEO, CADGME, E-LEARN, etc.);

-Initial and continuing training sessions for teachers (UDM, UAB, GRMS, etc.);

- Participation as appropriate in advisory bodies on training or technology programs (UDM, CCPÉ, MATI, etc.).

and of means, thanks to advanced technological skilled of team members:

-Community and sharing development platform for research quality (Turing, $\mathrm{cK} \varnothing$ wikibook, etc.), its integration (I2GÉO, NTLMP, etc.) and its popularisation

\footnotetext{
${ }^{2}$ We list acronyms and websites in the section References.
} 
(GIC-IGC, GeoGebraTube, etc.).

We are also planning to organise a workshop during phase 3 in collaboration with other research groups, so that researchers and teachers associated with a project can share their experiences following the first experimental phase. The formula proposed is a symposium, like the one we organised most recently in Montreal http:/turing.scedu.umontreal.ca/etm/, in the collaborative spirit typical of the Congress of European Research in Mathematics Education http://www.cerme8.metu.edu.tr, which balances quality (of seasoned researchers) and integration (of young researchers).

\section{Results Expected}

In the Knowledge mobilisation plan section, we insisted on the fact that the mutual contribution of didactics and computers generates research advantages and impacts within the university environment, with teachers and other stakeholders in the educational world, through interactions and increased access during the research itself.

By creating an "in use" tutorial system (within the meaning of [34]), our research approach is empirically based on the articulation and continuity between the institutional system design processes and the pursuit of the design in problem solving by the student. Since it was designed to produce a class of effects (support for learning through messages, problems and controls), implementation of the system, under the conditions provided for each phase of the project (see Detailed description section), allows updating of these effects following usage noted during experimental phases. In other words, if the cognitive outcome constitutes the design of the tutorial system, it is the source of its own existence by an expert anticipation of interactions of a of a changing student-milieu system. Unlike existing tutorial systems (see Background section), our choice of cognitive geometry is a significant mark of originality since it lets us both adapt the means of choice of the student's instrumented behaviour and integrate the specifics of authentic didactic contracts.

The idea of meeting a student's learning blockage by providing timely related problems to solve is an effective solution to one of the major difficulties in teaching: avoiding giving answers (discursive messages) at the same time as the questions (root problems). In this sense, our project theoretically answers the first didactic paradox of [7]: everything the teacher does to produce the expected behaviours by students tends to reduce the student's uncertainty and thereby deprives him of the necessary conditions for understanding and learning the intended concept; if the teacher tells or signifies what he wants from the student he can no longer get it other than as performance of an instruction and not by the exercise of his knowledge and judgement.
Apart from the institutional requirement for student training, the dissemination of knowledge and the influence on the community of researchers in the field, the integration of multidisciplinary doctoral research and the effective collaboration of the school institution remains a strategic advantage of the project, as is its influence on teachers practise and training. Whether first to improve students' geometrical skills, including deductive (reasoning, arguing), visual (observing, exploring), figural (modelling, conjecturing, defining) and operational (instrumentation, manipulation) skills, the potential for development of the tutorial system then allows the teacher to adapt a port of his pedagogical engineering according to the division of his responsibilities with those of the student. In initial training, these same arrangements sharpen students' abilities to simulate the effect of their teaching activities and to identify student's behaviour, since the anticipation of solutions up to planning (and not programming) learning itineraries adapted to the student.

The material benefits of our project are intended for public use in schools.

\section{Conclusions: Four Centres of Originality}

Although the current project is a continuation of the founding projects, it remains profoundly original in relation to it. We conclude by noting here four centres of originality.

A first centre relates to the organisation of a structure of related problems that responds to times of learning blockage by the student. Although desirable, this type of structure is unusual in math classes, since it is difficult to put in place in a paper-pencil environment and even if the use of related problems occasionally happens with some teachers, the choice of the problem remains limited by the environment. In addition, we know of no geometry tutorial system that integrates such organisation to restart a block problem solving process.

A second centre affects the joint consideration of the approaches to mathematical discovery and proof which, in the same context as instrumented learning, links the epistemology of mathematics with training programs. Attached to a reference geometry based first on the meaning of objects that it models and which makes as such an approximation possible, geometry becomes a means of learning and not longer its object, as is found with tutorial systems which develop geometric thinking by taking on an axiomatic approach.

A third centre relates to the functional modelling of knowledge in our tutorial system. Most of the time, a human learning computer environment is validated by comparing the results of a pre-test and a post-test, while requiring the user to comply with the system as it was designed. This attitude undoubtedly leads fairly quickly 
to concrete accomplishments, but it is necessary for these accomplishments to be effective learning aids. Although our tutorial system aims for effectiveness of the tutorial activity by first considering a modelling of human behaviour and designing a computer device which takes this model account, it is due to the structure of related problems is part of a learning model, distinct from the model of assessing mathematical competencies in an instrumented perspective.

A fourth centre looks at the non-deterministic character of the system and considers a large number of solutions. When a related problem is chosen, it is not so much because we know exactly why the student was blocked but because we suppose that the student knows what is expected of him and in return the teacher or the tutorial system knows the logic of the problem. The question of correlation between related a problem and a learning blockage is not deterministic since the system does not indicate how to proceed. It follows the student in his reasoning (by comparison with expert solutions generally in the range of 50-100,000), regardless if it belongs to a moment of discovery or proof and it invites him to remain in the logic of the situation, simultaneously offering personalised assistance based on the instrumented behaviour of each student in a single class.

\section{Acknowledgements}

The development of the research is made possible by a grant from the Conseil de recherches en sciences humaines (CRSH 410-2009-0179, Gouvernement du Canada) and a grant of the Secretaría de Estado de Investigación, Desarrollo e Innovación (EDU2011-23240, Gobierno de España).

\section{REFERENCES}

[1] V. Aleven, O. Popescu and K. R. Koedinger, "Towards Tutorial Dialog to Support Self-explanation: Adding natural Language Understanding to a Cognitive Tutor, dans Artificial Intelligence in Education: AI-ED in the Wired and Wireless Future (Éds. Moore, Redfield \& Johnson)," IOS Press, Amsterdam, 2002, pp. 246-255.

[2] C. Alsina and R. Nelsen, "Math Made Visual, Creating Images for Understanding Mathematics", Washington : the Mathematical Association of America, 2006. doi:10.5948/UPO9781614441007

[3] J. R. Anderson, C. F. Boyle and Yost, "The Geometry Tutor", The Journal of Mathematical Behavior, 1986, pp. 5-20.

[4] M. Artigue, "Ingénierie didactique, Recherches en didactique des mathématiques 9.3”, 1990, pp. 281-308.

[5] N. Balacheff and C. Margolinas, "Modèle de connaissances pour le calcul de situations didactiques, dans Balises pour la didactique des mathématique", (Éds. Mercier \& Margolinas), 2005, pp. 75-106. La pensée sauvage,
Grenoble.

[Overview of the model in line http://ckc.imag.fr/].

[6] M. Blossier and P. R. Richard, "Modélisation instrumentée et conceptions a priori dans un espace de travail géométrique en évolution : un tour en géométrie dynamique tridimensionnelle", Actes des journées mathématiques 2011 de l'École Normale Supérieure de Lyon (IFÉ 2011), Institut Français de l'Éducation , 2011, pp. 93-101.

[7] G. Brousseau, "Théorie des situations didactiques", La Pensée Sauvage, Grenoble, 1998.

[8] F. Caron and S. R. de Cotret, "Un regard didactique sur l'évaluation en mathématiques: genèse d'une perspective" Actes du Colloque 2007 du Groupe de didactique des mathématiques du Québec, 2007, pp. 123-134.

[9] A. C. Clairaut (2006), Éléments de géométrie, reproduction en fac-similé de l'édition de Paris chez David fils, 1741: Élémens de géométrie, Gabay, Paris.

[10] P. Cobo, J. M. Fortuny, E. Puertas and P. R. Richard, Agentgeom: A multiagent system for pedagogical support in geometric proof problems, International Journal of Computers for Mathematical Learning, Vol. 12, No. 1, 2007, pp. 57-79. doi:10.1007/s10758-007-9111-5

[11] S. Coutat and P. R. Richard, "Les figures dynamiques dans un espace de travail mathématique pour l'apprentissage des propriétés géométriques", Annales de didactique et de sciences cognitives, Vol. 16, 2011, pp. 97-126.

[12] J. J. Dahan, "La démarche de découverte expérimentalement médiée par cabri-géomètre en mathématiques : un essai de formalisation à partir de l'analyse de démarches de résolutions de problèmes de boîtes noires", Thèse de Doctorat, Université Joseph Fourier Grenoble, 2005.

[13] R. Duval, "Sémiosis et pensée humaine : Registres sémiotiques et apprentissages intellectuels", Peter Lang, Berne, 1995.

[14] R. Duval, "Les conditions cognitives de l'apprentissage de la géométrie : développement de la visualisation, différenciation des raisonnements et coordination de leurs fonctionnements", Annales de didactique et sciences cognitives, Vol. 10, 2005, pp. 5-53.

[15] M. A. Eisenhart, "The Ethnographic Research Tradition and Mathematics Education Research", Journal for Research in Mathematics Education, Vol. 19, No. 2, 1988, pp. 99-114. doi:10.2307/749405

[16] G. Gadanidis and P. R. Richard, "Report of the Working Group in MOOCs and Online Mathematics Teaching and Learning", Actes de la rencontre 2013 du Groupe canadien d'étude en didactique des mathématiques - Proceedings of the 2013 Canadian mathematics education study group conference, Brock University, 2013.

[17] B. G. Glaser and A. L. Strauss, "The discovery of grounded theory : Strategies for qualitative research," Aldine de Gruyter, Hawthorne, 1967.

[18] K. F. Hollebrands, A. M. Conner and R. C. Smith, "The Nature of Arguments Provided by College Geometry Students With Access to Technology While Solving 
Problems", Journal for Research in Mathematics Education, Vol. 41, No. 4, 2010, pp. 324-350.

[19] S. Johnston-Wilder and J. Mason, "Developing Thinking in Geometry", The Open University, 2005.

[20] A. Kuzniak, "Paradigmes et espaces de travail géométriques. Éléments d'un cadre théorique pour l'enseignement et la formation des enseignants en géométrie", Revue canadienne de l'enseignement des sciences, des mathématiques et des technologies, Vol. 6, No. 2, 2006, pp. 167-187.

[21] A. Kuzniak, "L'espace de travail mathématique et ses genèses", Annales de didactique et de sciences cognitives Vol. 16, 2011, pp. 9-24.

[22] A. Kuzniak, P. R. Richard and A. Gagatsis, "CERME7 Working Group 4: Geometry teaching and learning", Research in Mathematics Education, Vol. 14, No. 2, 2012, pp. 191-192. doi:10.1080/14794802.2012.694285

[23] Laboratoire Leibniz, "Baghera assessment project: Designing an hybrid and emergent educational society", dans Rapport pour la commission européenne, Programme IST, Les Cahiers du Laboratoire Leibniz $n^{\circ} 81$ (Éd. Soury-Lavergne). Grenoble, 2003.

[24] I. Lakatos, Preuves et réfutations. Essai sur la logique de la découverte mathématique. Hermann, Paris, 1984.

[25] V. Luengo, Some didactical and epistemological considerations in the design of educational software: The cabri-euclide example, International Journal of Computers for Mathematical Learning, Vol. 10, No. 1, 2005, pp. 1-29. doi.org/10.1007/s10758-005-4580-x

[26] C. Margolinas, Points de vue de l'élève et du professeur : essai de développement de la théorie des situations didactiques, Habilitation à diriger les recherches en sciences de l'éducation, Université de Provence, version électronique récupérée le 26 juillet 2010 à http://tel.archivesouvertes.fr/docs/00/42/96/95/PDF/HDR _Margolinas.pdf.

[27] J. Mason, Researching Your Own Practice: The Discipline of Noticing. Londres et New York: Routledge, 2005.

[28] N. Matsuda and K. VanLehn, "Advanced geometry tutor : An intelligent tutor that teaches proof-writing with construction", dans The 12th International Conference on Artificial Intelligence in Education (Éds. Looi, McCalla, Bredeweg \& Breuker), 2005, pp. 443-450. IOS Press, Amsterdam

[29] MÉLS (2001, 2006 et 2007), Programme de formation de l'école québécoise, éducation préscolaire, enseignement primaire (2001), enseignement secondaire $1^{\text {er }}$ cycle (2006) et enseignement secondaire $2^{\mathrm{e}}$ cycle (2007). Publications du Gouvernement du Québec.

[30] P. Paillé and A. Mucchielli, "L'analyse qualitative en sciences humaines et sociales", Paris : Armand Colin, 2008.

[31] M. J. Perrin-Glorian and Y. Reuter, "Les méthodes de recherche en didactiques", Villeneuve d'Ascq, France: Presses Universitaires du Septentrion, 2006.
[32] D. Py, Aide à la démonstration en géométrie : le projet Mentoniezh, Sciences et Techniques Educatives, Vol. 3, No .2, 1996, pp. 227-256.

[33] D. Py, "Environnements interactifs d'apprentissage et démonstration en géométrie", Habilitation à diriger des recherches, Université de Rennes, 2001.

[34] P. Rabardel, "Les hommes et les technologies : Approche cognitive des instruments contemporains", Armand Colin, Paris, 1995.

[35] P. Rabardel and Pastré, "Modèles du sujet pour la conception: dialectiques activités développement", Toulouse : Octarès, 2005.

[36] P. R. Richard, "Raisonnement et stratégies de preuve dans l'enseignement des mathématiques", Peter Lang, Berne, 2004a.

[37] P. R. Richard, "L'inférence figurale : Un pas de raisonnement discursivo-graphique", Educational Studies in Mathematics, Vol. 57, No. 2, 2004b, pp. 229-263. doi:10.1023/B:EDUC.0000049272.75852.c4

[38] P. R. Richard (2010a et b), "La geometría dinámica como herramienta para desarrollar competencias de modelización en el Bachillerato" (2010a), "La evaluación de competencias matemáticas : una apuesta de aprendizaje desde la elección de situaciones-problemas" (2010b), dans Competencias matemáticas. Instrumentos para las ciencias sociales y naturales (Éd. Chacón) 21-57 et 59-81. Publicaciones del Ministerio de Educación, Gobierno de España.

[39] P. R. Richard and J. M. Fortuny, “Amélioration des compétences argumentatives à l'aide d'un système tutoriel en classe de mathématique au secondaire", Annales de didactique et de sciences cognitives, Vol. 12, 2007, pp. 83-116.

[40] P. R. Richard, P. Cobo, J. M. Fortuny, M. Hohenwarter, "Training teachers to manage problem-solving classes with computer support", Journal of Applied Computing, Vol. 5, No. 1, 2009, pp. 38-50.

[41] P. R. Richard, J. M. Fortuny, M. Gagnon, N. Leduc, E. Puertas and M. Tessier- Baillargeon, "Didactic and theoretical-based perspectives in the experimental development of an intelligent tutorial system for the learning of geometry, dans Interoperable interactive geometry for Europe (Éds. Kortenkamp \& Laborde)", ZDM - The International Journal on Mathematics Education, Vol. 43, 2011, pp. 425-439.

[42] P. R. Richard, J. M. Fortuny, M. Hohenwarter and M. Gagnon, "geogebraTUTOR : une nouvelle approche pour la recherche sur l'apprentissage compétentiel et instrumenté de la géométrie à l'école secondaire", Actes de la World Conference on E-Learning in Corporate, Government, Healthcare, and Higher Education, 2007.

[43] P. R. Richard, V. Meavilla and J. M. Fortuny, "Textos clásicos y geometría dinámica : estudio de un aporte mutuo para el aprendizaje de la geometría", Revista Enseñanza de las Ciencias, Vol. 28, No. 1, 2010, pp. 95-111.

[44] P. R. Richard and A. Sierpinska, "Étude fonctionnelle-structurelle de deux extraits de manuels anciens de 
géométrie", In Lemoyne, G. et Sackur, C. (rédactrices invitées) Le langage dans l'enseignement et l'apprentissage des mathématiques, Revue des sciences de l'éducation, Numéro thématique, Vol. 30, No. 2, 2004, pp. 379-409.

[45] P. R. Richard, S. Coutat and C. Laborde, "L'apprentissage instrumenté de propriétés en géométrie : propédeutique à l'acquisition d'une compétence de démonstration", Educational Studies in Mathematics (sous presse), 2013.

[46] P. R. Richard, V. Freiman and D. H. Jarvis, "L'enseignement des mathématiques au Québec", Actes de l'Espace mathématique francophone 2012, groupe spécial Comparaison de l'enseignement des mathématiques à travers les pays francophones : résultats, sens et usages, Genève, 2013, pp. 7-30.

[47] P. R. Richard, E. Swoboda, M. Maschietto and J. Mithalal, "Introduction to the Geometrical Thinking Working Group", Actes du Congress of European Research in Mathematics Education (CERME8), 2013, pp. 1-7.

[48] A. H. Schoenfeld, "How We Think - A Theory of Goal-Oriented Decision Making and its Educational Applications", New York : Routledge, 2011.

[49] M. Tessier-Baillargeon, V. Leduc and P. R. Richard, "Niveaux d'intervention enseignante pour le développement d'un système tutorial : une expérience didactique à l'école secondaire avec le système géogébraTUTOR", Actes des journées mathématiques 2011 de l'École Nor- male Supérieure de Lyon (IFÉ 2011), Institut Français de l'Éducation, 2011, pp. 201-208.

[50] M. Tessier-Baillargeon, N. Leduc and P. R. Richard, "Développement expérimental d'un système tutoriel intelligent pour le développement de compétences en géométrie à l'école secondaire". Dans Formation à la recherche en didactique des mathématiques (Éds. Hitt \& Cortés), pp. 101-113. Québec : Loze-Dion.

[51] J. Trgalová and P. R. Richard, “Analyse de ressources comme moyen de développement professionnel des enseignants", Actes de l'Espace mathématique francophone 2012, groupe de travail Ressources et développement professionnel des enseignants, 2012, pp. 12-23, Genève.

[52] J. Trgalová, P. R. Richard and S. Soury-Lavergne, "Évaluation de la qualité des ressources de géométrie dynamique : un outil pour le développement de compétences professionnelles des enseignants de mathématiques", Actes des journées mathématiques 2011 de l'École Normale Supérieure de Lyon (IFÉ 2011), Institut Français de l'Éducation, 2011, pp. 131-138, Lyon.

[53] J. M. Van der Maren, "Méthodes de recherche pour l'éducation", De Boeck Université, Bruxelles, 1996.

[54] K. Vanlehn, C. Lynch, K. Schulze, J. A. Shapiro, R. Shelby, L. Taylor, et al., "The andes physics tutoring system : Lessons learned”, Int. J. Artif. Intell. Ed., Vol. 15, No. 3, 2005, pp. 147-204.

[55] P. Vermersch, L'entretien d'explicitation en formation initiale et continue, ESF, Paris, 1994. 


\section{References to main websites}

$\mathrm{cK} \notin$ wikibook

GeoGebraTube

GDM

GIC-IGC

I2GÉO

Turing
http://ckc.imag.fr/index.php/Main_Page

http://www.geogebratube.org

http://turing.scedu.umontreal.ca/gdm/

http://www.geogebracanada.org/home

$\mathrm{http} / / / \mathrm{i} 2 \mathrm{geo}$.net (access to activities for registrants)

http://turing.scedu.umontreal.ca (access to Moodle for registrants)

\section{Acronym reference}

AC-GGB Associació Catalana de geogebra

ADSC Annales de didactique et de sciences cognitives

AMQ Bulletin of the Association mathématique du Québec

CADGME Computer Algebra and Dynamic Geometry Systems in Mathematics Education

CCPÉ Advisory Committee on the curriculum of the Quebec Ministry of Education

CERME Congress of European Research in Mathematics Education

CRSH Conseil de recherche en sciences humaines du Canada

E-LEARN World Conference on E-Learning in Corporate, Government, Healthcare \& Higher Education

EMF Espace mathématique francophone Symposium

ESM Educational Studies in Mathematics - An International Journal

ETM Symposium Espace de travail mathématique

GRMS Group of leaders in high school mathematics

IJCML International Journal of Computers for Mathematical Learning

INTERGEO Interoperable Interactive Geometry Conference

MATI Roland-Giguère training and learning technologies House

NTLMP International Newsletter on the Teaching and Learning of Mathematical Proof

PME Publicaciones del Ministerio de Educación de España

REC Revista enseñanza de las ciencias - Investigación y experiencias didácticas

UAB Universitat Autònoma de Barcelona

UDM Université de Montréal

UNO Revista Uno - Didáctica de las matemáticas

ZDM Zentralblatt für Didaktik der Mathematik - The International Journal on Mathematics Education 